\title{
Recruitment of Science and Mathematics Teachers: Findings from Three Years Efforts of a Recruitment Program
}

\author{
Kadir Demir ${ }^{\mathrm{a}}$, Tugce Gul ${ }^{\mathrm{b}}$, Charlene Czerniak $^{\mathrm{c}}$ \\ ${ }^{a}$ Georgia State University, USA; ${ }^{b}$ Columbus State University, USA; ${ }^{c}$ University of Toledo, USA
}

\begin{abstract}
Across the US there is a shortage of highly qualified science and mathematics teachers. To alleviate the problem, Federal, state, and local government and agencies have been enacted to improve the quality of education while reducing teacher shortages. Consequently, many agencies, such as the NSF, the U.S. Department of Education, and the U.S. Department of Energy, to name a few, have awarded large grants to universities and other organizations to implement mathematics and science teacher recruitment programs and prepare teachers to deliver high quality instruction. These programs vary greatly in terms of their target populations, the type and frequency of the early teaching experience provided, the academic and financial support systems, and the public relations campaigns. Given the urgency of the national mathematics and science teacher shortage and the high cost of these programs, examining their impact is critical. In this paper, we present findings from three years' efforts of a science and mathematics teachers recruitment program to start mapping the landscape of teacher recruitment. Our discussion and implications suggest that more strategic efforts are need while recruiting students, especially minorities, at all career levels (direct from high school, transfer from community college, change of major, and career changers).
\end{abstract}

Keywords: Teacher shortage, recruitment, science and mathematic teachers

\section{The Shortage of Science and Mathematics Teachers: Alive and Well}

The shortage of qualified science and mathematics teachers (SMT) is not a new problem in the United States (U.S.). Schorling documented this shortage, especially in secondary schools, as early as 1947 and in 1985, Levin reaffirmed that the severity of the shortage had been existed for decades. However, it is in the last two decades that securing a sufficient force of highly qualified SMT to staff U.S. public schools has become one of the most pressing concerns in education groups across the country (Barth, Dillon, Hull, \& Higgins, 2016; Goldhaber, Lavery, \& Theobald, 2015). According to Barth et al., fewer students are entering to teacher education programs and enrollments in traditional and alternative programs declined by 30 percent between 2010 and 2014 . The reasons for the severe SMT include, but not limited to, aging of the current teaching force, low-salaries, classsize reduction initiatives, teacher attrition, and the increased number of science and math credits many school districts require for high school graduation (e.g., Feistritzer, 1998; Haberman, 2001; Ingersoll, Merrill, \& Stuckey, 2014; National Center for Education Statistics, 2005; Podolsky, Kini, Bishop, \& Darling-Hammond, 2016; Schaefer, 1999; Struyvena, \& Vanthournout, 2014; Teitelbaum, 2003; U.S. Department of Education [USDOE], 2001). In addition, as Newton et al. (2010) point out, recruiting highly qualified college graduates with a major in a STEM field is a challenge due to the

${ }^{1}$ Corresponding author: Kadir Demir, Georgia State University Department of Middle and Secondary Education P.O Box 3978 Atlanta, GA 30302 Email: kadir@gsu.edu

Demir, K., Gul, T., \& Czerniak, C. (2019). Recruitment of Science and Mathematics Teachers: Findings from Three Years Efforts of a Recruitment Program. Journal of Research in STEM Education, 5(2), 119-137. 
myriad of non-teaching STEM careers that offer a significantly higher starting salary than teaching.

The shortage of SMT impacts the quality of teaching that K-12 students experience. Reported percentages vary slightly, but they all indicate that only a small fraction of the nation's SMT hold a degree in their teaching fields (Committee on Science, Engineering, \& Public Policy, 2007; Ingersoll, 1999; Goldhaber et al., 2015; National Academies of Sciences, Engineering, and Medicine, 2015; USDOE, 2000). Another aspect of the teacher shortage problem is that it exacerbates social injustices as it is most marked in high poverty schools, high minority urban and remote rural schools (Ingersoll \& May, 2011, 2012). For example, 30\% of the SMT who take positions at urban schools end up leaving the profession within their first three years and those who stay oftentimes adjust by doing the minimum to get by (National Commission on Teaching and America's Future, 1996). A recent survey study conducted in the state of Georgia with over 53,000 educators on the possible reasons for this attrition affirms Ingersoll and May's findings. According to the study, $44 \%$ of newly hired Georgia teachers dropped-out of the profession by year five. This attrition rate is more worrisome considering that there was a 16\% dip from 2010 to 2014 in the number of candidates entering Georgia's teacher preparation programs (Georgia Department of Education [GADOE], 2015). As a result, the teaching force, especially in math and science, in high poverty and urban schools is of dramatically lower quality than that of high affluent neighborhoods where teachers' tenure is longer (GADOE, 2015; Ingersoll, 1999, 2002; Ruhland \& Bremer, 2002; Stoddart \& Floden, 1995). A similar trend occurs in lower-track classes, where most needy and low achieving students often end up having the least effective teachers (Lynch, Kuipers, Pyke, \& Szesze, 2005).

Policies and Programs to Recruit Science and Mathematics Teachers

To cope with teacher shortages, Federal, state, and local government and agencies (e.g., NSF, USDOE, States, and local school districts) have acted through policies and programs focusing on increasing recruitment, retention, and quality of teachers. One policy implemented is alluring potential teacher candidates with financial incentives, such as increasing benefits and scholarships (Education Week, 2000; Kirby, Darling-Hammond, \& Hudson, 1989; Liou, \& Lawrenz, 2011). For example, the federal government allocated scholarships (e.g., Robert Noyce Teacher Scholarship and the Teacher Education Assistance for College and Higher Education [TEACH] Grant Programs) and teacher loan forgiveness programs (e.g., Stanford Loan Forgiveness for Teachers and Teacher Cancellation for Federal Perkins Loans) to states to help districts recruit, train, and retain quality teachers. However, neither these policies nor traditional teacher education programs have been able to promptly produce enough SMT. The federal government has also allocated grant money to a wide range of programs to improve the quality of teaching and make the teaching profession more attractive to current and potential new teachers (e.g., Improving Teacher Quality State Funds, Transition to Teaching, Teacher Incentive Funds, etc.). In 2013, for example, Congress appropriated $\$ 2.9$ billion for these teacher programs (Atlas, 2013). Many of these financially supported teacher education programs expose qualified undergrads to teaching experiences (e.g., the University of Texas-Austin UTeach program).

More intense alternative certification policies have also been implemented. By 2015, fortyeight states and the District of Columbia had implemented at least one such program (USDOE, 2015). For 2017 fiscal year, USDOE requested $\$ 12.9 \mathrm{~B}$ for the TEACH Grant program that awards annual grants of up to $\$ 4,000$ to eligible undergraduate and graduate students who agree to serve as full-time teachers in mathematics, science, foreign language, bilingual education, special education, or reading at a high-need school (USDOE, 2017). In 2013, for example, USDOE awarded six grants totaled about $\$ 30 \mathrm{M}$ for teacher recruitment. Teach for America (TFA) program, which is an alternative program, was one of the six awardees. TFA planned on preparing 12,500 new teachers over the two years following the award. Even with all of the government funding for recruitment, the issue remains unaddressed as both universities and alternative teacher licensure programs continue to find it difficult to recruit prospective mathematics and science teachers. And the success of the policies and programs implemented has met with mixed reviews (Cavanagh, 2007). Thus, it may be the time to examine the issues associated with recruitment of SMT. 


\section{Why People Choose Teaching as A Profession?}

There are a wide variety of reasons for choosing a teaching career. These factors may include a sense of vocation, an initial long-term commitment to the profession, or the influence of specific people on the future teacher's career decision as well as unpredictable (e.g., pregnancy, unemployment) and contingent factors (e.g., geography). Research suggests that the motivation to pursue a teaching career may fall into three categories: (a) altruistic reasons, such as enjoying working with children and contributing to society; (b) intrinsic reasons, such as studying subject matter, academic development, and engaging with the activity of teaching; and (c) extrinsic reasons, including, pay, social status, work schedule, and working conditions (e.g., Brown, 1992; Brown \& Butty, 1999; Chuene, Luben, \& Newson, 1999; DeLong, 1987; Eick, 2002; Heinz, 2015; Howes \& Goodman-Delahunty, 2015; Stokes \& Tyler, 2003; Wang, 2004). To illustrate, in a study in which Kyriacou and Coulthard (2000) compared the views of teaching held by undergraduates found out that undergraduates definitely did not consider teaching and only cited extrinsic factors such as good promotion prospects and 'high earnings over length of career' as important. The undergraduates who were attracted to teaching viewed characteristics such as 'a job that gives me responsibility' (intrinsic), 'a job where I can contribute to society' (altruistic) and 'job mobility' (extrinsic) as important in their future career.

Early exposure to teaching, whether in formal or informal settings, is identified as a prominent factor on career decision of those who were (dis)interested in teaching or may have not thought about teaching as a career option (e.g., Taylor, 2006; Tomanek, 1996; Tomanek \& Cummings, 2000; Valadez, 2003). Apparently, the factors influencing teaching career decisions are more embedded in the socio-cultural contexts. In the U.S., King's (1993) and Valadez's (2003) studies revealed that society negatively influenced the decision to become a teacher. Lack of prestige, poor working conditions, and media reports on negative issues in teaching were some of the societal factors recognized by research participants. However, in Taiwan, Wang (2004) reported positive societal influences on the research participants' teaching career choices. Results illustrate that favorable government policies, cultural beliefs about teaching, appealing working conditions, and the high social status of teaching attributed were some of the reasons cited by the research participants for choosing teaching as a career. Finally, the Watt and Richardson's (2007) framework summarized the factors mentioned above and also included the positive influences of prior learning experiences, individuals' perception of teaching in terms of task demands and returns, self-perception of teaching ability, and a fallback career construct which accounts for individuals who have been unable to pursue their first-choice career or who were unsure of their career choice and defaulted to teaching careers.

\section{Effective Teacher Recruitment Strategies}

The reasons for selecting a teaching career posited in the previous section helps explain why school districts and universities use certain recruitment strategies to attract individuals into teaching. Research on successful methods for recruiting teachers into science and mathematics (Garibaldi, 1989; Howes \& Goodman-Delahunty, 2015; Liou, \& Lawrenz, 2011; Oakes, 2001; Sears, Marshall, \& Otis-Wilborn, 1994; Tomanek, 1996) can be summarized into five strategies: recruitment campaigns, early exposure to teaching, academic support systems, financial support systems, and public relations.

\section{Recruitment Campaigns}

Campbell and Spiro (1982) found that newspaper ads and direct mailing were the most costeffective means by which to reach potential students. While radio ads were relatively low in cost, only about $9 \%$ of their survey respondents $(n=255)$ heard about their continuing education program through radio ads. Television advertisement was found not to be cost-effective at all. Details as to the extent of use of each of the advertising mediums were not provided. Berger and Wallingford (1996) suggested that more personal outreach efforts can be effective, such as open houses, advertising specialties like calendars with important dates for applying included, and direct mail of promotional items, such as brochures or flyers. According to Abell et al., (2006) and Demir, Martin-Hansen, Gul, \& Puvirajah (2012) digital media platforms, e.g., Facebook, provide excellent outreach with which 
to recruit teachers.

Opportunities for prospective and current student teachers to interact with those who are in teacher education seem to have positive impacts on one's decision to pursue a career in teaching. According to Wright and Custer (1998)'s study, the number one factor was interaction with university faculty $(37 \%)$, followed closely by being impressed with facilities at the university. The least effective means of recruiting was a personal letter from someone currently in the teacher education program $(6 \%)$. When recruiting from minority groups, Kim (2006) found that interaction with faculty and the presence of role models who reflect the groups' ethnicity were effective recruitment methods. Carrier and Cohen (2005) and Littleton (1998) noted collaboration between colleges and school districts increased the number of mid-career people who return for licensure specifically to teach in urban settings. The pool they tapped included substitute teachers and paraprofessionals or aids who already worked in urban schools.

\section{Early Exposure to Teaching and Field Experiences}

Prior positive teaching experiences (no matter how informal), career opportunities, and the perceived possession of personal attributes beneficial to teaching are found to be positive motivators to pursue teacher education. Hammond (2002) reported that pre-service teachers credited their previous positive experiences with teaching, mentoring, or guiding students as most influential in their decisions to become teachers. Teacher candidates argued that the experiences provided them with new confidence, purpose, fulfillment, and an appealing introduction to inquiry-based learning. Jenkins (1998) found that, in occasions, initial choice of a science teaching career included reasons such as simply trying out teaching as one possibility among many. Numerous university-based recruitment programs (e.g. the Science Majors as Teaching Interns Project, Tomanek \& Cummings, 2000; the Oregon Collaborative for Excellence in the Preparation of Teachers, Enneking, 2003; the Teaching Scholars Recruitment Initiative, Shulman \& Armitage, 2005; and GK-12 programs, Trautmann, 2008), offered STEM undergraduates pedagogical training along with K-12 or college teaching experiences. A common finding was that the participants claimed significant contribution of the teaching experience for recruitment purposes, as they increased their interest, passion in teaching, and knowledge of teaching's demanding realities. Those experiences were also helpful to those who had initially thought about teaching; then decided not to pursue teaching as a career. These participants cited the demands placed on teachers, the high needs of students, and the lack of cooperation on the part of parents as their reasons for choosing alternative careers. However, given that the programs include other components along the teaching experience, it is uncertain that the reported effect of increased interest in teaching careers is solely the consequence of the teaching experience.

\section{Academic Support}

Academic support structures provided by universities, such as advising, student professional organizations, and learning communities are important considerations in recruiting teachers (e.g., Clewell \& Forcier, 2001; Jacullo-Noto, 1991; Villegas \& Davis, 2007). Villegas and Davis uttered that, once admitted to a teacher education program, prospective teachers need to receive academic support services for retention and a timely completion of their program, e.g. support with steering the complexities of the higher education bureaucracy.

\section{Financial Support}

Research indicated that financial assistance is a positive element in making the decision to enroll in a particular school or program as opposed to another. Yet, according to Berger and Wallingford (1996), prospective students must be in the advanced stages of decision-making which is the conviction stage (see the six stages model for commitment by Kotler \& Armstrong, 1991) before scholarships and other financial incentives are influential. They found out that in the conviction stage, the students placed the institution or program at or near the top of their choices. Financial assistance, therefore, is more attractive after much of the recruiting efforts have been set forth. 


\section{Public Relations}

Sinclair, Dowson, and MacInerney (2006) found that the most common motivators for one to pursue teaching included the desire to work with children, the value placed upon teaching, intellectual stimulation, and helping others. They did not, however, find that ease of entry and work dissatisfaction with previous employment to be strong motivators for selecting teaching as a career. These findings are oftentimes used to develop public relations strategies that aim to attract students to teaching who place high value on working with children and helping others. Common public relations strategies are found in public service announcements run on television and radio, as well as in ads in local newspapers, regarding the personal satisfaction associated with working with children and teaching.

\section{Purpose of the Study}

Many teacher recruitment programs around the nation are facing the challenge to attract qualified candidates into science and mathematics teaching. Therefore, a study of how these aforementioned motivators operate to prompt an individual to pursue a teaching career would help to make these programs more efficient. This paper aimed to further our knowledge about: (a) promising recruitment strategies; (b) characteristics of science and mathematics teacher candidates in the Teach Science \& Math (TSM); (c) factors contributing to those candidate's decision whether to pursue teaching career; (d) candidates' entry points to the TSM. We believe that construction of these characteristics makes a meaningful contribution to the existing knowledge base of teacher education and provides useful directions for recruiting future science and mathematics teachers.

\section{Context of Study}

The TSM was a federally funded science and mathematics teacher education recruitment program housed at Midwestern university. It was developed on the basis of existing research-based literature and modeled after other successful programs (e.g. UTeach in Austin, Texas). The TSM program was designed to recruit, better prepare, and retain SMT for urban schools. TSM recruited potential teacher candidates from a pool of high school seniors/pre-college students as well as professionals who sought a career change. The TSM provided the opportunity for professionals with strong mathematics or science content backgrounds to earn a teaching license and master's degree in less than two years. The program was a multi-leveled partnership among four colleges at the university where the TMS program was situated (the Colleges of Education, Arts and Sciences, Engineering, and Pharmacy), the local public-school system and the local Catholic school system. Additional supporting partners included the city zoo, the city science center, and a few other community organizations that offered exposure to teaching children.

\section{The TSM Recruitment Efforts}

Those undecided potential candidates in their career choice were encouraged to explore teaching as a profession. For example, only about a third of the freshmen who enter the College of Pharmacy continue to the upper division. Many of these students, having completed several courses in chemistry and other sciences, may explore the possibility of becoming a high school science teacher. Similarly, recent graduates with Bachelor of Science with majors in a mathematics or science disciplines were also encouraged to consider coming back to retool for a teaching career. Thus, the goal was not to take students from other colleges who "wash out" of their programs, but rather to better inform students early in their Freshman year of career possibilities in teaching, attract students from the aforementioned fields who are better suited for teaching, and who have stronger interests in teaching than they originally thought when they enrolled in these other colleges. Therefore, at the outset of implementing the program, TSM recruitment efforts were centered upon five successful research-based strategies (recruitment, early exposure to teaching, academic support systems, financial support systems, and public relations) for recruiting and retaining potential teacher candidates into urban science and mathematics teaching described erstwhile. A dedicated recruiter was hired to assist with those recruitment efforts and hosting and facilitating open houses. Following, we provide a brief description of these key components utilized in the TSM program. 


\section{Early Exposure to Teaching}

TSM students were introduced to teaching during a 3-week residential Summer Institute and a 6-week academic year initiative. The experience was specifically designed to acquaint talented minority pre-college high school students (incoming junior or senior) with the practical aspects of teaching and create opportunities for academically talented students to interact with successful science and mathematics teachers. During the summer institute, participating TSM students were given opportunities to: (a) interact with master teachers and college professors; (b) plan science and mathematics activities; (c) teach younger students in classroom and community settings using teaching strategies and activities they learned about in the program; and (d) discover if science or mathematics teaching profession was right for them. Following the summer institute, students continued to be a part of the program for another six weeks during the school year. Meantime, the TSM program provided paid internships for prospective undergraduate teacher candidates to engage in applied work experiences in science or mathematics fields. The internships were for 10 hours per week and could be renewed up to two semesters. Students had an opportunity to work with urban youth in settings such as the city Zoo, the city science center, the university's planetarium, the local Boys and Girls Clubs, and other community agencies.

\section{Academic Support Systems}

The Exploring Urban Mathematics/Science Teaching (Exploring) Course was developed to recruit high quality STEM undergraduate students and graduate students interested a career change. This three credit-hour course was first offered during the Fall semester of the Year 1 and throughout the TSM program. The TSM program paid the tuition for students who took this course, in which the average enrollment was 15. Though the course design improved knowledge and skills for teaching, it was also designed to give participants an early field experience with teaching in an urban environment. It provided students with background, training, tools, and practice prior to allowing them to actually teach. Much time was spent observing teachers (both video and direct observation), participating in a case study of teaching, discussions about and exploration of different teaching styles and approaches, the unique aspects of teaching in an urban school (e.g. working with students who had limited English language skills, who were at risk for academic failure, who came from low socioeconomic backgrounds, and who represented a variety of ethnicities) and student journals about what they were observing and learning about teaching. Additionally, the course allowed students to experience innovative technologies used in the classroom. Most importantly, it provided a context to candidates to determine through self-analysis if the teaching profession was right for them.

\section{Public Relations}

The TSM employed several public relations strategies to help communicate the importance of becoming a science or mathematics teacher and recruit potential students to the program. A website was created to provide information to both prospective students and the people who were associated with the program (e.g., teachers, principals, advisors). Additionally, a monthly newsletter was sent to area schools and community leaders. The newsletter typically included information about the program and success stories about the graduates. Finally, there were several 30 and 60 -second radio and TV Public Service Advertisements designed to interest students in taking science and mathematics in school as well to recruiting teachers into science or mathematics teaching.

\section{Financial Support Systems}

Besides tuition waiver for the Exploring course and paid internships, the TSM program worked with the university Financial Aid Office to identify scholarships, grant, and loan forgiveness programs to assist students with financial issues. Students were made aware of the Federal Loan Forgiveness for science and mathematics teachers if they taught in high need/low income school districts that were listed in the Annual Directory of Designated Low-Income Schools for Teacher Cancellation Benefits. With U.S. Department of Education funding, the TSM program also provided students with up to $\$ 12,800$ in financial assistance (in the form of financial aid or merit scholarships). Students who received Financial Aid and Merit Scholarships had to agree to teach in high need 
schools for the length of time they received financial support. Otherwise, they were required to repay the money to the U.S. Department of Education.

\section{Methodology}

We used a holistic single-case study approach (Yin, 2013) to study recruitment efforts of science and mathematics teachers to the TSM program. Case studies are used to explore bounded systems such as an event, process, or program that we have no in-depth perspective about (Yin, 2013). Thus, the case study method allowed us to retain the holistic and meaningful characteristics and decision points of those who were thinking about science or mathematics teaching as a career and those who were recruited to the TSM program in the first three years.

\section{Data Collection}

We employed multiple sources of data, as in the use of questionnaires for carrying out a survey, semi-structured interviews, archival records and documents (e.g. student records, program files, e-mails, open-house data such as surveys and signing sheets, and inquiries). Data from those multiple sources provided information about the circumstances that surrounded potential applicants' interest in becoming science or mathematics teachers, parts of the TSM program they found to be attractive, how they learned about the TSM program, and what, if anything, prevented them from enrolling in the program.

The TSM's archival data set consisted, but not limited to electronic records (such as followup emails); Exploring course enrollment; old-fashioned (paper) files; recruitment materials (such as brochures, electronic media, new paper ads); information on those who did not enroll to the program and those program participants' demographic and background information (e.g. degree obtained, year of graduation, current careers, they knowledge of the TSM, how did find out about the TSM etc.); and open-ended questionnaires/surveys (Open House and Thoughts about the Teaching Profession questionnaire). The resulting archival data were both quantitative and qualitative. Open house questionnaire included nine open-ended questions focusing on the issues of recruitment and respondents' reasons for career choices, especially teaching (see Appendix A). From the four open house events spanned over the last two years of our data collection, we collected data from 41 participants. Thoughts about the Teaching Profession questionnaire was administered only to TSM' newly admitted students at the beginning of the program. The survey focused on the participants' disposition towards teaching and learning (see Appendix B for sample survey items). Data obtained from 63 TSM participants using this questionnaire. There was any overlap between the two sets of the participants as there was only one student recruited through Open House efforts over the years period (see Table 2).

To acquire more substantial information on the issues of recruitment, participants' decisions and decision points on choosing a teaching career either in science or mathematics, and the TSM program structure and recruitment efforts, we conducted 10 semi-structured interviews (Seidman, 2015) carried in a conversational mode with a subset of Exploring course participants (see Appendix $C$ for sample interview questions). These interviews were used to complement open-ended surveys used at different stages of the program. Each of these interviews lasted between one hour and half to two hours. Participants were randomly selected among the 87 Exploring course participants. Once selected, they were extended an invitation to participate in the research study. Participation was voluntary and consent form detailing study purpose and procedures was provided to each research participant. The participants' construction of reality provided important insights into the case.

\section{Data Analysis}

The availability of multiple data sources produced an imperative opportunity for triangulation, as we were able to continually check and recheck the consistency of the findings from different as well as the same sources (Yin, 2013). This allowed us to establish converging lines of evidence in making our findings as robust as possible. Our data analysis began by systematically organizing our data (narratives and words) into hierarchical relationships, matrices, and creating 
tables to present both qualitative (narrative) and quantitative data in the cells of tables (Miles \& Huberman, 1994). Our analysis did not start with any predicted patterns, but in fact it started with open-ended research questions that lead to the use of an explanation-building technique (Yin, 2013). With regard to this approach, when the data set was complete, Thematic Analysis was used as our first coding method to define the significant elements of our open-ended research questions and to check the alignments of the research questions. In pursuit of this, to reorganize and reanalyze the data, we used Pattern Coding as a second cycle coding method (Saldaña, 2013). This enabled us to distill and pull together the primary categories into a more meaningful and parsimonious unit of analysis (e.g., impact of the Exploring Course). The analysis concluded with carefully constructed analytic generalizations of our findings. In doing so, we attempted to show how our study's findings informed the relationships among recruitment strategies utilized by the TSM, participants' decision on entering the teacher education program or not entering, and the TSM's program components effect on the recruitment and retention.

\section{Findings}

The original TMS program's focus was on recruiting students at all career levels (direct from high school, transfer from community college, change of major, and career changers). As a result, staff and resources had been spread very thin in an attempt to produce and distribute a variety of literature in print and electronic form, talk to school counselors, send staff to various campus events such as Freshman Orientation and Undecided Majors Fairs in addition to the myriad of other strategies used (showed in Figure 1). As an outcome of those recruitment efforts, the number of inquiries made about the program went up from 65 in year one to 199 in year two, and to 246 in year 3 (See Table 1 for detailed information).

Table 1.

Results: Total Inquires Made to the TSM by the end of Year 3

\begin{tabular}{|c|c|c|c|}
\hline Source of program fall and spring information & Number o & & \\
\hline January to December & Year 1 & Year 2 & Year 3 \\
\hline Personal contact & 53 & 157 & 154 \\
\hline Advisor/faculty & 33 & 79 & 90 \\
\hline Friend/classmate/family & 5 & 12 & 23 \\
\hline Contact UT/COE/UT3 office & 7 & 13 & 12 \\
\hline High school teacher/counselor & 1 & 2 & 4 \\
\hline Referred by another university & & 4 & \\
\hline Quest-Undecided students & 1 & 1 & 1 \\
\hline The Source & & 6 & \\
\hline UT3 presentations & & & \\
\hline Majors Fair & 1 & 5 & 12 \\
\hline Rocket Launch & 5 & 5 & \\
\hline Open House & & 2 & 3 \\
\hline EXCEL program/TUMSA & & 1 & 3 \\
\hline Freshman Orientation & & 1 & 1 \\
\hline Career Day & & 2 & 2 \\
\hline Masters Presentation & & 4 & 3 \\
\hline Internet (Website/email) & 4 & 6 & 19 \\
\hline Letter/Card in the mail & 3 & 4 & 5 \\
\hline
\end{tabular}


Media

Sign/Flyer

Radio/TV

Newspaper Ads (Blade, local papers \& UT News)

Toledo Blade Article

\begin{tabular}{l|ccc}
\hline Unknown & 3 & 20 & 14 \\
\hline Total & 65 & 199 & 246 \\
\hline
\end{tabular}

By the end of year 3, a total of 57 students had been recruited. However, as shown in Table 2, there was a decline in the number of recruited students, 20 students in year one, 20 students in year two, and 17 in year three.

To be accepted into the TSM, students had to meet both the college and the program's admission requirements. By the end of year three, 125 applicants submitted applications. Of these applications, only 89 were complete to be reviewed by the program's scholarship committee. The remaining 36 applicants did not complete their files to be considered for full review, though the program coordinator and staff made several attempts to each individual to remind them of their incomplete application files. The scholarship committee awarded 76 applications after a detailed review. Fifty-seven of these applicants, including 4 people who dropped out from the program by the end of spring semester in year three, enrolled to the program.The 19 applicants who were awarded scholarship, but did not enroll to the TSM decided to not pursue a career in teaching for a variety of reasons such as change in major, finding a job, or program length. On the other hand, the 13 applicants who were rejected for scholarship by the committee because of a range of reasons, such as low GPA or indication of low commitment for teaching profession, were not declined permanently. Depending on their circumstances, they were offered some alternative pathways, e.g. either to take the Exploring course or an internship and advised to reapply afterwards, or, if they had low GPAs, then they were asked to reapply once they met the College of Education's requirements.

Table 2.

TSM Students (subset from Table 1)

\begin{tabular}{|c|c|c|c|}
\hline Source of program information & Number & & \\
\hline Enrolling in School Year/Receiving \$ & Year 1 & Year 2 & Year 3 \\
\hline Personal contact & 17 & 19 & 15 \\
\hline College Contact - Advisor/faculty & 14 & 10 & 10 \\
\hline Friend/classmate/family & 3 & 4 & 5 \\
\hline High school teacher/counselor & & 2 & \\
\hline UT3 presentation & & 1 & \\
\hline EXCEL program & & 1 & \\
\hline Internet & & & 2 \\
\hline Letter in the mail & 3 & & \\
\hline Newspaper & & 1 & \\
\hline Total & 20 & 20 & 17 \\
\hline
\end{tabular}

By the end of spring semester in year three, 87 students had taken the Exploring course (59 students seeking undergraduate degrees while 28 of them were seeking master's degrees). Nineteen of these students had been accepted to the program, and 16 of these students were required to take the explore course, so they could explore teaching and learning of science and mathematics before making a commitment. The course was originally intended as a recruiting mechanism for undecided students through early field experience with teaching, yet it turned out to be a confirmatory experience. Even majority of the students, who decided not to pursue teaching as a career, recognized the 
benefits of experiencing real teaching environment (e.g. pros and cons of teaching), some hesitated to participate to the TSM due to a long-term commitment after graduation. For instance, during an interview with Nate, he argued, "I don't really know what I want to do directly after graduation. The main problem I have with [TSM] is the length of the commitment. The only thing I heard about it was like 5-year commitment after college." Contrarily, interviews and surveys conducted with those students who had made their mind about becoming either a science or mathematics teacher indicated that the course served as an assenting tool and the financial support that was not an influential factor in their decision. To them, financial support was a bonus. Furthermore, the course served to those committed students as a mean of exploring urban teaching. To illustrate, "It gave us the opportunity to really look and see like how teachers can be and what we want to be and how we don't want to be towards the students and stuff...I had my heart set on teaching," stated Angela. Those committed students typically took the course to develop a greater confidence in their decision to teach and to broaden their comfort zone by exploring urban teaching in particular. For example, Daniel, in an interview before he taking the course, stated, "Becoming an urban teacher would definitely be very difficult just because of motivational issues really. Students don't care to learn and to do well." During the course, Daniel realized that positive rapport and meaningful pedagogical practices were some of the key factors in connecting with students. "I found out that teaching is really more than just talking to students. It's about interacting with students and getting them do hands-on things, apparently that's huge," said Daniel. Thus, those students who were attracted to the course were not undecided about teaching as a whole, but tended to be undecided about whether or not they wanted to be urban educators. Data collected from these students also revealed that they tended to agree more at the end of the semester that teacher education is more important than a natural teaching ability in the development of good teaching practices.

The survey, entitled Thoughts about the Teaching Profession, was administered to the TMS programs' newly admitted students. Results provided interesting information regarding student's dispositions. Of the total 63 respondents (9 from Exploring class and 54 from orientation group) to the survey, $49 \%$ said that a desire to help others was the reason they decided to pursue a teaching career. Thirty-three percent indicated they wanted a career where they could work with children and $27 \%$ said that they had some teaching experience and loved it, early exposure to teaching.

Data collected via interviews and surveys, including incomplete applications and open house data, revealed that previous positive teaching experiences were the most common characteristics of all induvial across the board. It did not differentiate whether they enrolled to the program either at undergraduate or graduate level or inquired about the program. For example, 32 of 41 people who participated in open house surveys in the fall Year 1 and sprig Year 2 indicated that they had some prior teaching experience, such as through tutoring, law firm, and summer camp (see Table 3). Similarly, all students who were enrolled to or had graduated from the TMS program, except two, indicated that they had some previous teaching experiences (see Table 2). 
Table 3.

TSM Students' Responses to Open House Questionnaire

\begin{tabular}{ll}
\hline Questions & \\
\hline Whose opinions do you care about in terms of your choice of career? & \\
My own & \\
Family & \\
Teachers & 6 \\
Friends & 6 \\
When did you first think about becoming a teacher? & 4 \\
Elementary school & 10 \\
Middle School & \\
High School & \\
College & 110 \\
Graduate School & \\
Other jobs & 30 \\
At this point, how committed are you to pursuing a teaching career? \\
Seriously considering \\
Possibly considering \\
Why are you interested in becoming a math or science teacher? \\
Like teaching to youths \\
Enjoy science/math \\
Feel strong in math/science \\
Have enthusiasm in teaching (to make a difference) \\
Career change \\
Need qualified teachers in math/science
\end{tabular}

Have you had any prior teaching experience such as tutoring, Sunday school,

teacher aid, teacher assistant, etc.?

Substitute teacher in high school 10

Tutoring 12

College teaching $\quad 8$

Sunday school 4

Teaching assistant 6

What aspects of math or science teaching are most attractive to you? 37

Like math/science 24

Make people excited about science 3

Problem solving techniques $\quad 5$

Influence students' future careers 5

What aspects of math and science teaching are least attractive to you? 22

Boring 2

Less self-efficacy 6

Students' lack of interest and behavioral problems 8

Requirements (i.e., preparation time, grading, homework, standardized 6 tests, etc.)

What strategies you think could be taken to make the teaching profession more attractive?

Commitment to help students' learning (i.e., hands-on and interactive 6

strategies) 4

Enjoying and satisfaction of teaching 2

Parental involvement 5

Financial incentives 4

Mentoring teachers

Is there anything that would help attract you to a teaching career?

Financial incentives

Already attractive (by TSM) 10

Mentor/Support 3

Programs to fast tracks in becoming teacher 3 
Research data indicated that most of the teacher candidates seriously started to think about teaching either at college -at late stages as junior or senior undergraduate student- or after college while working on other jobs rather than thinking about teaching at earlier ages. This finding was also supported by findings from Excel program (a component of our recruitment whereby high school students attended a summer program about teaching). The Excel portion of the program, which was designed to recruit talented minority high school students to science or mathematics teaching, had resulted in recruiting only on student. Yet, the Excel program reinforced some of those students' existed desire to pursue a career in science or mathematics teaching. Angele said, "I always used to play teacher growing up, so I always had that thought in my head" [interview]. Similarly, Jason claimed, "From all the enjoyment and excitement from teaching in the summer time, I figured why not do this as a year around type of thing." In the first three years of the program, 39 students participated in the summer institute: 15 students in year one, 13 students in year two, and 11 students in year three. Although at the end of year three, we were able to recruit only one student from Excel the data revealed that they enjoyed working with students who were younger than them and they gained a broader view of what science or mathematics teaching entails, e.g. challenges, content knowledge, etc. Excel students' data at the end of the summer sessions unveiled that most of them had already made their minds for other career choices such as pharmacy, engineering and medicine. Interest in teaching, as a career, for those high school students, remained a second or third choice. They cited personal interest and salary as the top two factors that were fundamental to their decision of why they would pursue their career choice.

Lastly, follow up interviews conducted with potential students who requested more information, but did not apply for the TMS program indicated that most were not interested in teaching in a high needs area to fulfill the service requirements of the scholarships. This was especially true with undergraduate students in their first two years of their program. With this in mind, the TSM personnel made some substantial changes in recruitment effort toward target populations, e.g., the TSM recruitment personnel shifted the recruitment efforts to seek candidates who had the dispositions toward teaching, but not necessarily toward urban teaching initially and toward individuals who were either upper division undergraduates or second career Masters-level students.

\section{Discussion, Conclusion, and Implications}

This study aimed to further our knowledge about: (a) promising recruitment strategies; (b) characteristics of science and mathematics teacher candidates in the Teach Science \& Math (TSM) program; (c) factors contributing to those candidate's decision whether to pursue teaching career; (d) candidates' entry points the TSM. Over the course of the TSM program, we anticipated a greater number of applicants than we were able to recruit. This challenge led us to ask ourselves, "What are the most success recruitment strategies associated with recruiting prospective science and mathematics teachers who want to teach in urban schools?" Thorough examination of the TSM data from year one to year three indicated that most of the individuals who inquired about the TSM program found out about the program through personal contact, including, but limited advisor/faculty, the TSM faculty and staff presentations, friends/classmate/family, contact University/COE/TSM office, etc. (see Table 1). By the end of year 3, personal contact remained to be the most significant method of recruitment.

The open house events included opportunities for prospective teachers to meet with the TMS faculty and students. Findings from the four open house surveys revealed that the majority of attendees, overall, felt the faculty presentations and the question and answer period to be the most informative aspect of the program, including discussion that took place among prospective and the TSM program students. The Exploring course was a great medium not only for proving situated teaching and learning opportunities for the program participants to explore urban science and mathematics teaching, but also enabling them to make their minds towards teaching as a career. The TSM undergraduate participants reported that they gained a better understanding of teaching. They agreed that the Exploring course reinforced their career choices whether to pursue or not 
teaching as a career (Singh \& Billingsleya, 1998). Thus, it can be claimed that the Exploring course acted as an efficient career selection tool for participants to help them make the best choice even before they enter the pipeline. Also, participating in the Exploring course served as platform to the TSM participants as the course seemed to have more of a confirmatory effect rather than a significant recruitment strategy (Moin, Dorfield, \& Schunn, 2005).

Regarding informal educational experiences, all students in the TSM program discussed rich informal educational experiences centered around family, community, and/or church (see Table 3). These results indicate that, at least partially, factors that underlie the decision to choose a certain route to certification in secondary science and mathematics (i.e., alternative vs. traditional) and the timing to do so (i.e., later vs. directly after earning a college degree) relate to more distal than proximal factors. These latter factors seem to be mainly related to family background and early formal and informal educational experiences.

While extrinsic motivations were chief among the universe of career changers, these motivations were the main reason for only a portion of the undergraduate population. This population seemed more disposed to consider a teaching career and only when they felt low intrinsic motivation (no interest in teaching) or low altruistic motivation (no interest in teaching at disadvantaged settings) the pursue of a teaching career became unlikely. Intrinsic and altruistic reasons include trying teaching and more involvement in the discipline (intrinsic) and working with children and helping others (altruistic). Based upon these findings, we targeted our outreach to emphasize or provide opportunities to experience the rewarding aspects of helping others to learn and working with children or adolescents. This outreach included participation in the Exploring course. By the end of year three, we promoted these ideas in newspaper advertisements aimed at prospective students who were invited to one of two open houses.

Over a three-years period of recruitment efforts, we observed some challenges with recruiting SMT for urban schools that were either associated with the TSM recruitments efforts or as a results of external factors, e.g., college admission recruitments, personal factors, policies, etc. The most prevalent challenges included: a) recruitment of minority participants; b) college credit and admission requirements; c) logistical factors for undergraduate students; d) ceiling for recruitment; e) service requirement; and f) timing. It was a difficult task for the TSM program as it mostly targeted the white population.

Recruitment of minority participants. Despite the TMS's purposeful targeted recruitment efforts to recruit minorities through minority churches, schools, newspapers, neighborhoods, etc. the outcomes were not at desired level that the TMS program wished to have.

College credit and admission requirements. For the TSM, education requirements both from the College of Education to attain teaching certification and from disciplinary courses to complete content credit requirements for a master degree, were a deterrent to potential candidates.

Logistical factors for undergraduate students. While low teacher salaries were a deterrent factor for career changers, it did not seem to be a factor for undergraduate student population for participating in the TSM's recruitment efforts. For them, common barriers for program participation were logistic in nature (such as missing the deadline and scheduling conflicts). A fair number of undergraduates who attended informational events, but did not apply to the program reported lack of time for participating in the program. This last aspect may suggest that these individuals might have other career priorities such as research or application, and teaching may have been their fallback career (Watt \& Richardson, 2007).

Ceiling for recruitment: The assumptions that there are a lot of people out there that can be recruited for integrating the science or mathematic teaching force seems to be incorrect from our experience, especially minorities and urban teachers. This seems to be the case for the TSM program as well. Although the TSM recruitment efforts increased and expanded more strategically from year 1 to year 3 the number of teacher candidates who were recruited decreased. This finding is in agreement to previous findings of Moin et al. (2005). 
Service commitment. The federal government required a year of service in a high need school for each year the student received a scholarship. This was perceived as impediment both by undergraduate students and career changers. While undergraduate students did not want to make long-term teaching commitments potential teacher candidates, on the other hand, were not interested in teaching in a high needs area to fulfill the service requirements of the scholarship. Thus, the scholarship tended to be a more attractive enticement to those students who have entered the program with fewer years of service commitment.

Timing. From the undergraduate population, the late undergraduate years seem to be the time when more candidates are interested in the participating in a recruitment program. The TMS programs did not have high recruitment of freshmen and sophomores. This finding is in agreement with Moin et al. (2005) who concluded that upper level STEM undergraduates are a more appropriate target for teacher recruitment efforts compared with freshman and sophomores. Similar results were observed with Excel Program, designed to recruit talented minority high school students to science or mathematics teaching, as well as the efforts only resulted in recruiting only on student high school students to undergraduate teacher education program. This results aligns well with the findings of Summerhill, Myrna, Peltier, \& Hill (1998).

Our discussion and implications suggest that more strategic efforts are need while recruiting students, especially minorities, at all career levels (direct from high school, transfer from community college, change of major, and career changers). As it was discussed earlier, comprehensive examination of the TSM data from year one to year three indicated that most of the individuals who inquired about the TSM program and recruited to TSM were through personal contacts and efforts. Thus, we would suggest that teacher recruitment programs, especially those that are targeting minorities, to invest their human and financial resources into personal efforts, e.g., advising and promoting the program with the help faculty in undergraduate and graduate programs that are relevant to the focus of the recruitment efforts.

\section{References}

Abell, S., Boone, W., Arbaugh, F., Lannin, J., Beilfuss, M., Volkmann, M., \& White, S. (2006). Recruiting future science and mathematics teachers into alternative certification programs: Strategies tried and lessons learned. Journal of Science Teacher Education, 17, 165-183.

Atlas. (2013). Federal programs for Prek-12 teachers. Retrieved from http://atlas.newamerica.org/federalprograms-k-12-teachers

Barth, P., Dillon, N., Hull, J., \& Higgins, B. H. (2016). Fixing the holes in the teacher pipeline: An overview of teacher shortages. Retrieved from http://www.centerforpubliceducation.org/system/files/Teacher\%20 Shortage_0.pdf

Berger, K. A., \& Wallingford, H. P (1996). Developing advertising and promotion strategies for higher education. Journal of Marketing for Higher Education, 7(4), 61-72.

Brown, J. W., \& Butty, J-A. M. (1999). Factors that influence African American male teachers' educational and career aspirations: Implications for school district recruitment and retention efforts. Journal of Negro Education, 68, 280-292.

Brown, M. M. (1992). Caribbean first-year teachers' reasons for choosing teaching as a career. Journal of Education for Teaching, 18, 185-195.

Campbell, J. F., \& Spiro, L. M. (May, 1982). Evaluation of the impact of media marketing strategies on continuing education enrolments. Paper presented at the annual forum of the Association for Institutional Research, Denver, CO.

Carrier, K., \& Cohen, J. A. (2005). Hispanic individuals in their communities: An untapped resource for increasing the bilingual teacher population. Journal of Hispanic Higher Education, 4(1), 51-63.

Cavanagh, S. (2007). Doubts cast on math, science teaching lures. Education Week, 26(43), 1.

Chuene, K., Luben, F., \& Newson, G. (1999). The views of preservice and novice teachers on mathematics teaching in South Africa related to their educational experience. Educational Research, 41(1), 23-34.

Clewell, B. C., \& Forcier, L. B. (2001). Increasing the number of mathematics and science teachers: a review of teacher recruitment programs. Teaching and Change, 8, 331-361. 
Committee on Science, Engineering, and Public Policy. (2007). Rising above the gathering storm: Energizing and empowering America for brighter economic future. Washington, DC: The National Academies Press.

DeLong, T. J. (1987). Teachers and their careers: Why Do They Choose Teaching? Journal of Career Development, $14,118-125$.

Demir, A., Martin-Hansen, L., Gul, T., \& Puvirajah, A. (2012, May). Facing the recruitment challenges: Facebook for recruitment. Paper presented at the Annual Robert Noyce Scholarship Conference, Washington, DC.

Education Week. (2000). Quality Counts 2000: Who Should Teach? Retrieved from http://www.edweek.org/ media/ew/qc/archives/QC00full.pdf

Eick, C. J. (2002). Studying career science teachers' personal histories: A methodology for understanding intrinsic reasons for career choice and retention. Research in Science Education, 32, 353-372.

Enneking, M. (2003). Oregon collaborative for excellence in the preparation of teachers: An overview. The Journal of Mathematics and Science: Collaborative Explorations, 6, 1-9.

Feistritzer, E. (1998). Alternative teacher certification: An overview. Retrieved October 15, 2004, from http://www. ncei.com/Alt-Teacher-Cert.htm

Garibaldi, A. M. (1989). Teacher recruitment and retention with a special focus on minority teachers. Washington, DC: National Education Association.

Georgia Department of Education (2015). Op-ed by superintendent Woods: Teacher recruitment and retention survey results. Retrieved from http://www.gadoe.org.

Goldhaber, D., Lavery, L., \& Theobald, R. (2015). Uneven playing field? Assessing the quality gap between advantaged and disadvantaged students. Educational Researcher, 44, 293-307.

Haberman, M. (2001). The creation of an urban normal school: What constitutes quality in alternative certification? Educational Studies, 32, 278-288.

Hammond, M. (2002). Why teach? A case study investigating the decision to train to teach ICT. Journal of Education for Teaching, 28(2), 135-148.

Heinz, M. (2015). Why choose teaching? An international review of empirical studies exploring student teachers' career motivations and levels of commitment to teaching. Educational Review and Evaluation, $21,258-297$.

Howes, L. M \& Goodman-Delahunty, J. (2015). Teachers' career decisions: Perspectives on choosing teaching careers, and on staying or leaving. Issues in Educational Research, 25(1), 18-35.

Ingersoll, R. M. (1999). The problem of underqualified teachers in American secondary schools. Educational Researcher, 28(2), 26-37.

Ingersoll, R. M. (2002, June). The teacher shortage: A case of wrong diagnosis and wrong prescription. NASS Bulletin, 86, 16-31.

Ingersoll, R. M., \& May, H. (2011). Recruitment, retention and the minority teacher shortage. Consortium for Policy Research in Education. Retrieved from http://www.cpre.org/sites/default/files/researchreport/1221_ minorityteachershortagereportrr69septfinal.pdf

Ingersoll, R. M., \& May, H. (2012). The magnitude, destinations, and determinants of mathematics and science teacher turnover. Educational Evaluation and Policy Analysis, 34, 435-464.

Ingersoll, R., Merrill, L. \& Stuckey, D. (2014). Seven trends: the transformation of the teaching force. Consortium for Policy Research in Education. Retrieved from https://repository.upenn.edu/cpre_researchreports/79

Jacullo-Noto, J. (1991). Minority recruitment in teacher education: Problems and possibilities. Urban Education, 26, 214-230.

Jenkins, E. W. (1998). On becoming a secondary science teacher in England: A pilot study. International Journal of Science Education, 20, 873-881.

Kim, K. S. (2006). Recruiting and retaining students of color for LIS schools: Perspectives from librarians of color. Retrieved on September 11, 2006 from http://slisweb.lis.wisc.edu/ kskim/Diversity.htm.

King, S. H. (1993). Why did we choose teaching careers and what will enable us to stay?: Insights from one cohort of the African American teaching pool. Journal of Negro Education, 64, 475-492.

Kirby, S. N., Darling-Hammond, L., \& Hudson, L. (1989). Nontraditional recruits to mathematics and science teaching. Educational Evaluation and Policy Analysis, 11, 301-323.

Kotler, P. \& Armstrong, G. (1991). Marketing (6th ed.). Englewood Cliffs, NJ: Prentice-Hall.

Kyriacou, C., \& Coulthard, M. (2000). Undergraduates' views of teaching as a career choice. Journal of Education for Teaching, 26, 117-126.

Levine, H. M. (1985). Solving the shortage of mathematics and science teachers. Educational Evaluation and Policy Analysis, 7, 371-382.

Liou, P., \& Lawrenz, F. (2011). Optimizing teacher preparation loan forgiveness programs: Variables related to perceived influence. Science Education, 95, 121-144. 
Littleton, D. M. (1998). Preparing paraprofessionals as teachers for the urban classroom: A university/school collaborative model. ERIC Document Reproduction Service No. ED442798.

Lynch, S., Kuipers, J., Pyke, C., \& Szesze, M. (2005). Examining the effects of a highly rated science curriculum unit on diverse students: Results from a planning grant. Journal of Research in Science Teaching, 42, 912946.

Miles, M. B., \& Huberman, A. M. (1994). Qualitative data analysis (2nded.). Thousand Oaks, CA: Sage Publications.

Moin, L. J., Dorfield, J. K., \& Schunn, C. D. (2005). Where can we find future K-12 science and math teachers? A search by academic year, discipline, and academic performance level. Science Education, 89, 980-1006.

National Academies of Sciences, Engineering, and Medicine. (2015). Science Teachers Learning: Enhancing Opportunities, Creating Supportive Contexts. Washington, DC: The National Academies Press.

National Center for Education Statistics (2005). School and Staffing Survey (SASS) and Education. Retrieved from http://nces.ed.gov/survey/SASS/

National Commission on Teaching and America's Future. (1996). What matters most: Teaching for America's future. New York: Author.

Newton, X. A., Jang, H., Nunes, N., \& Stone, E. (2010). Recruiting, preparing, and retaining high quality secondary mathematics and science teachers for urban schools: The Cal Teach experimental program. Issues in Teacher Education, 19(1), 21-40.

Oakes, J. (2001). The governor's teacher scholar initiative: Can the University of California bring highly qualified teaching to the state's poorest children? Teacher Education Quarterly, 28(1), 57-69.

Podolsky, A., Kini, T., Bishop, J., \& Darling-Hammond, L. (2016). Solving the teacher shortage: How to attract and retain excellent educators. Palo Alto, CA: Learning Policy Institute.

Ruhland, S. K., \& Bremer, C. D. (2002). Alternative teacher certification procedures and professional development opportunities for career and technical education teachers. St. Paul, MN: National Research Center for Career and Technical Education.

Saldaña, J. (2013). The coding manual for qualitative researchers. Los Angeles, CA: Sage Publications.

Schaefer, N. (1999). Traditional alternative certification: A view from the trenches. In M. Kanstoroom \& C. E. Finn, Jr. (Eds.), Better teachers better schools (pp. 137-161). Washington, DC: The Thomas B. Fordham Foundation.

Schorling, R. (1947). The crisis in science and mathematics teaching. School Science and Mathematics, 47, 413-420.

Sears, J. T., Marshall, J. D., \& Otis-Wilborn, A. (1994). When best doesn't equal good. Educational reform and teacher recruitment, a longitudinal study. New York: Teachers College Press.

Seidman, I. (2015). Interviewing as qualitative research: A guide for researchers in education and the social sciences (3rd ed.). New York, NY: Teachers College Press.

Shulman, V., \& Armitage, D. (2005). Recruiting teachers for the urban classroom: The teaching scholars initiative. New Educator, 1, 231-249.

Sinclair, C., Dowson, M., \& Mcinerney, D. M. (2006). Motivations to teach: Psychometric perspectives across the first semester of teacher education. Teachers College Record, 108, 1132-1154.

Singh, K., \& Billingsley, B. S. (1998). Professional support and its effects on teachers' commitment. The Journal of Educational Research, 91, 229-239.

Stoddart, T., \& Floden, R. E. (1995). Traditional and alternative routes to teacher certification: Issues, assumptions, and misconceptions. East Lansing, MI: National Center for Research on Teacher Learning.

Stokes, H., \& Tyler, D. (2003). Senior secondary students' attitudes to teaching as a career. Retrieved from http:// www.dest.gov.au/NR/rdonlyres/84881380-DA33-4DDC-88E5-76D01A79D424/1664/student_attitudes. pdf

Struyvena, K., \& Vanthournout, G. (2014). Teachers' exit decisions: An investigation into the reasons why newly qualified teachers fail to enter the teaching profession or why those who do enter do not continue teaching. Teaching and Teacher Education, 43, 37-45.

Summerhill, A, Myrna, M., Peltier, G., \& Hill, G. (1998). High school seniors' perceptions of teaching career. Journal of Teacher Education, 49, 228-234.

Taylor, A. (2006). Perceptions of prospective entrants to teacher education. Teaching and Teacher Education, 22, 451-464.

Teitelbaum, P. (2003). The Influence of High School Graduation Requirement Policies in Mathematics and Science on Student Course-Taking Patterns and Achievement. Educational Evaluation and Policy Analysis, 25, 31-57.

Tomanek, D. (1996). Creating interest in teaching: Science classroom experiences for academically talented college science majors. The Journal of Science Teacher Education, 7, 213-225. 
Tomanek, D., \& Cummings, K. E. (2000). The use of secondary science classroom teaching assistant experiences to recruit academically talented science majors into teaching. Science Education, 84, 212-227.

Trautmann, N. M. (2008). Learning to teach: Alternatives to trial by fire. Change, 40(3), 40-45.

U.S. Department of Education (2000). Progress through the teacher pipeline: 1992-93 college graduates and elementary/ secondary school teaching as of 1997. NCES 2000-152. Washington DC: National Center for Education Statistics. Retrieved from http://nces.ed.gov/pubsearch/pubinfo.asp?pubid=2000152

U.S. Department of Education. (2001). The condition of education: 2001. Washington, DC: Author.

U.S. Department of Education. (2015). Highly qualified teachers enrolled in programs providing alternative routes to teacher certification or licensure. Washington, DC: Author.

U.S. Department of Education. (2017). Fiscal year 2017 budget summary and background information. Retrieved from https://www2.ed.gov/about/overview/budget/budget17/summary/17summary.pdf

Valadez, J. P. (2003). High school students' perceptions of becoming an educator: A case study in South Texas. ERIC Document Reproduction Service No: ED474073.

Villegas, M. A., \& Davis, D. E. (2007). Approaches to diversifying the teaching force: Attending to issues of recruitment, preparation, and retention. Teacher Education Quarterly, 34(4), 137-147.

Wang, H-H. (2004). Why teach science? Graduate science students' perceived motivations for choosing teaching as a career in Taiwan. International Journal of Science Education, 26, 113-128.

Watt, H. M. G., \& Richardson, P. W. (2007). Motivational factors influencing teaching as a career choice: development and validation of the FIT-choice scale. Journal of Experimental Education, 75, 167-202.

Wright, M. D., \& Custer, R. L. (1998). Why they want to teach: Factors influencing students to become technology education teachers. Journal of Technology Education, 10, 58-70.

Yin, R. (2013). Case study research: Design and methods (5th ed.). Thousand Oaks, CA: Sage Publications. 


\section{Appendix A: Open House Questionnaire}

Whose opinions do you care about in terms of your choice of career? When did you first think about becoming a teacher?

Have you had any prior teaching experience such as tutoring, Sunday school, teacher aid, teacher assistant, etc.?

At this point, how committed are you to pursuing a teaching career?

Why are you interested in becoming a math or science teacher?

What aspects of math or science teaching are most attractive to you?

What aspects of math and science teaching are least attractive to you?

What strategies you think could be taken to make the teaching profession more attractive?

Is there anything that would help attract you to a teaching career?

\section{Appendix B: Sample Items from Thoughts about the Teaching Profession Questionnaire}

Please note your level of agreement with the following statements about teaching and the teaching profession. Because this measures your opinion, there is no "correct" answer to any of these questions. Circle the number from 1 to 6 that best represents your level of agreement where

$$
1=\text { no agreement } \quad \text { and } \quad 6=100 \% \text { agreement } .
$$

1. I am committed to becoming a teacher

$\begin{array}{llllll}1 & 2 & 3 & 4 & 5 & 6\end{array}$

2. I would like to teach in an urban school.

$$
\begin{array}{llllll}
1 & 2 & 3 & 4 & 5 & 6
\end{array}
$$

3. Teachers have a good deal of job security.

$\begin{array}{llllll}1 & 2 & 3 & 4 & 5 & 6\end{array}$

4. When taking into account salary, benefits, and time off, teachers are well-compensated.

$\begin{array}{llllll}1 & 2 & 3 & 4 & 5 & 6\end{array}$

5. A teacher training program is more important than a natural teaching ability in the development of good teachers.

$\begin{array}{llllll}1 & 2 & 3 & 4 & 5 & 6\end{array}$

6. Why did you decide to consider teaching?

7. Why have you enrolled in this course?

8. If you are not totally committed to a teaching career, please list career possibilities other than teaching that you are considering. For each one, add a number in brackets to indicate the strength of your commitment. 


\section{Appendix C: Sample Semi-Structured Interview Questions}

- What can you tell me about your previous work experience? (career changers)

- What teaching experience have you had in teaching science/mathematics prior enrolling in the TSM?

- What factors influenced your decision to enter science or mathematics teaching?

- In your opinion, what are the general factors that (might be) important to you when choosing a career?

- In your opinion, what is science/mathematics teaching entail?

- What did prompt your change from previous employment to begin a career in teaching?

- What role has society played in influencing your decision to pursue a career in teaching?

- What aspects of teaching science or mathematics do you believe make it easier to teach science or mathematics?

- What aspects of teaching science or mathematics do you believe make it harder to teach science or mathematics?

- Thorough your experiences at Exploring class, have you found teaching to be better or worse that than what you have expected?

- As you consider not choosing a career in teaching what aspects or considerations of another job have you considered?

- Could you name any changes that might make you rethink about choosing a career in teaching? 